Research article

\title{
ANTIDEPRESSANT EFFECTS OF AN INVERSE AGONIST SELECTIVE FOR $\propto 5$ GABA-A RECEPTORS IN THE RAT FORCED SWIM TEST
}

\author{
SAMARDŽIĆ Janko ${ }^{1 *}$, PUŠKAŠ Laslo ${ }^{2}$, OBRADOVIĆ Miljana ${ }^{3}$, LAZIĆ-PUŠKAŠ \\ Dijana ${ }^{4}$, OBRADOVIĆ I Dragan ${ }^{1}$
}

${ }^{1}$ Institute of Pharmacology, Clinical Pharmacology and Toxicology, Medical Faculty, University of Belgrade, Dr Subotića 1, Belgrade, Serbia; 'Institute of Anatomy "Niko Miljanić", Medical Faculty, University of Belgrade, Dr Subotića 4, Belgrade, Serbia; ${ }^{3}$ Institute of Histology and Embriology, Medical Faculty, University of Belgrade, Višegradska 26, Belgrade, Serbia; ${ }^{4}$ Clinic for Psychiatric Diseases "Dr Laza Lazarevic", Belgrade, Serbia and Faculty of Special Education and Rehabilitation, University of Belgrade, Visokog Stevana 5, Belgrade, Serbia

(Received 24 December 2013; Accepted 28 January 2014)

It has been shown in electrophysiological studies that the ligand L-655,708 possesses a binding selectivity and a moderate inverse agonist functional selectivity for $\alpha 5$-containing GABA-A receptors. The present study is aimed to investigate the antidepressant effects of the ligand L-655,708 in the forced swim test (FST) and its impact on locomotor activity in rats. The behavior of the animals was recorded with a digital camera, and the data were analyzed by one-way ANOVA, followed by Dunnett's test. In FST, L-655,708 significantly decreased immobility time at a dose of $3 \mathrm{mg} / \mathrm{kg}$ after a single and repeated administration $(\mathrm{p}<0.05)$, exerting acute and chronic antidepressant effects. However, it did not induce significant differences in the time of struggling behavior during FST. Furthermore, L-655,708 did not show a significant effect on locomotor activity $(\mathrm{p}>0.05)$. These data suggest that negative modulation at GABA-A receptors containing the $\alpha 5$ subunit may produce antidepressant effects in rats. These effects were not confounded by locomotor influences.

Key words: GABA-A receptor, Inverse agonist, Depression, Forced swim test, Locomotor activity.

\section{INTRODUCTION}

The majority of fast inhibitory neurotransmissions in the central nervous system (CNS) is governed by the action of $\gamma$-aminobutyric acid (GABA) type A receptors (GABA-A). The complex structure and function of GABA-A receptors and benzodiazepine binding sites was recently elucidated [1]. GABA-A receptors are pentameric membrane proteins that operate as GABA-gated $\mathrm{Cl}^{-}$channels. The majority contains a benzodiazepine binding site located at the interface of the $\gamma_{2}$-subunit and the respective $\alpha$-subunit $\left(\alpha_{1}\right.$, $\left.\alpha_{2}, \alpha_{3}, \alpha_{5}\right)[2]$.

At these receptors, there are several modulatory sites, which mediate the actions of many drugs, among them benzodiazepines [2]. Three kinds of allosteric modulators

*Corresponding author: e-mail: jankomedico@yahoo.es 
act through the benzodiazepine binding site: positive (agonist), neutral (antagonist), and negative (inverse agonist) modulators [3]. It is established that agonists at the benzodiazepine site present anxiolytic and amnesic properties, whereas inverse agonists could exert opposite actions [4,5].

Recent genetic studies with mice carrying a point mutation in $\alpha 1, \alpha 2, \alpha 3$ or $\alpha 5$ subunits have suggested a specific contribution of individual receptor subtypes to the spectrum of behavioral actions of these compounds [6]. These genetic advances have encouraged the synthesis and testing of new, selective BZ site ligands, that possess stronger affinity and/or efficacy profiles [7]. Here, we focus on $\alpha 5$-containing GABA-A receptors, as these receptors are highly expressed in brain regions substantially involved in memory formation and emotion [8-10]. Previous evidence from animal studies has shown that the $\alpha 5$-containing GABA-A receptors were significantly involved in cognition [11-14]. Moreover, it has been shown that a negative modulation of $\alpha 5$ GABA-A receptors may represent an attractive treatment option for cognitive impairments, and potentially positive symptoms, associated with schizophrenia [15].

The goal of the present study was to examine the influence of the inverse agonist 11,12,13,13a-tetrahydro-7-methoxy-9oxo-9H-imidazo $\quad[1,5-a]$ pyrrolo[2,1-c] $\quad[1,4]$ benzodiazepine -1-carboxylic acid, ethyl ester (L-655,708), previously characterized by Atack et al. [11], acting on $\alpha 5$-subunit-containing GABA-A receptor and compare its dose-response effects on locomotor activity and depression-like behavior in the forced swim test.

\section{MATERIALS AND METHODS}

\section{Animals}

Experiments were carried out on male Wistar rats (Military Farm, Belgrade, Serbia) weighing 180-230 g. The rats were housed in transparent plastic cages, six animals per cage, and had free access to pelleted food and tap water before and after drug administration. The animals were placed in a room kept at a temperature of $22 \pm 1$ ${ }^{\circ} \mathrm{C}$, relative humidity $40-70 \%$, and $12 / 12$-h light/dark period (lights on at $0630 \mathrm{~h}$ ). All handling and testing took place during the light portion of the cycle. The animals (6 rats per treatment group) had been used only once throughout our study, after they were used in other trials. All procedures in the study were confirmed to EEC Directive 86/609 and approved by the Ethical Committee on Animal Experimentation of the Medical Faculty in Belgrade.

\section{Drugs}

L-655,708, the inverse agonist selective for $\alpha 5 \mathrm{GABA}_{\mathrm{A}}$ receptors, was obtained from Sigma-Aldrich (Poole, Dorset, UK). The substance was dissolved in a vehicle containing saline (80\%) and dimethylsulphoxide (20\% DMSO, from Sigma-Aldrich), and injected intraperitoneally in a volume of $1 \mathrm{ml} / \mathrm{kg}$. 


\section{Forced swim test}

The forced swimming test, described by Porsolt et al. [16], was performed in a glass cylinder, $45 \mathrm{~cm}$ high, $20 \mathrm{~cm}$ diameter filled with water up to a height of $30 \mathrm{~cm}$, with a temperature of $21-23{ }^{\circ} \mathrm{C}$. Male Wistar rats were exposed to two swimming sessions (an initial 15-min pretest session, followed $24 \mathrm{~h}$ later by a 5 -min test session). Time of administration and doses of L-655,708 were chosen based on previous studies by Attack et al. [11]. The animals received i.p. 0.3, 1, and $3 \mathrm{mg} / \mathrm{kg}$ of L-655,708 or saline, $30 \mathrm{~min}$ before the test session. The duration of immobility (seconds) was scored during the 5-min test session and the rat was considered immobile whenever it floated passively in the water and only made movements necessary to keep its head above the water line. The time of struggling (seconds) during the 5-min test session consists of explosive muscular movements against the apparatus wall, in an attempt to escape from the cylinder. After the test, the rat was removed from the tank, dried with a towel, and placed back in its home cage. The water in the swim tank was changed between rats. In the experiment with the repeated drug application, on the first day, male Wistar rats were forced to swim for $15 \mathrm{~min}$ (pretest session). The rats were removed and randomly divided into two treatment groups. Solvent or L-655,708 (3 mg/ kg) were administered, intraperitoneally, once a day for 14 days. Rats were re-exposed to the FST, for a single 5-min session, $24 \mathrm{~h}$ after the last drug administration.

\section{Spontaneous locomotor activity}

The measurement of spontaneous locomotor activity was performed in a clear Plexiglas box $(40 \times 25 \times 35 \mathrm{~cm})$, immediately after the application of increasing doses of L-655,708 $(0.3,1$, and $3 \mathrm{mg} / \mathrm{kg})$ or solvent. Time of administration and doses of L-655,708 were chosen based on previous studies [11]. To asses the spontaneous locomotor activity, the total distance traveled under dim red light $(20 \mathrm{~lx})$, was monitored by a digital camera placed above the box, for a total of $30 \mathrm{~min}$, without any habituation period. Recording ofanimal activity and processing data were conducted by computer software ANY-maze Video Tracking System (Stoelting Co., Wood Dale, IL, USA).

\section{Statistical analysis}

All numerical data presented in the figures were given as the mean \pm S.E.M. An alpha level of 0.05 was used for all statistical tests. In the forced swim test, the behavior of the animals was recorded by a digital camera, and data were analyzed by one-way ANOVA, followed by Dunnett's test. Spontaneous locomotor activity behavior was recorded by a digital camera, analyzed by the ANY-maze software.

\section{RESULTS}

\section{Forced swimming}

In the forced swim test, during the test session, ANOVA indicated statistically significant effects of L-655,708 $(\mathrm{F}(3,20)=6.42, \mathrm{p}<0.05)$. L-655,708 significantly decreased immobility time at the highest applied dose of $3 \mathrm{mg} / \mathrm{kg}$, exerted acute antidepressant- 
like effects (Figure 1). However, L-655,708 did not induce significant differences in the time of struggling behavior during the test (data not shown).

In the experiments with repeated administration, a significant effect of treatment $(\mathrm{F}(1,18)=4.779, \mathrm{p}<0.05)$ has been described. The administration of L-655,708, once a day for 14 days, significantly decreased the immobility time in the FST, when compared with the solvent-treated group, confirming antidepressant effects (Figure 2).

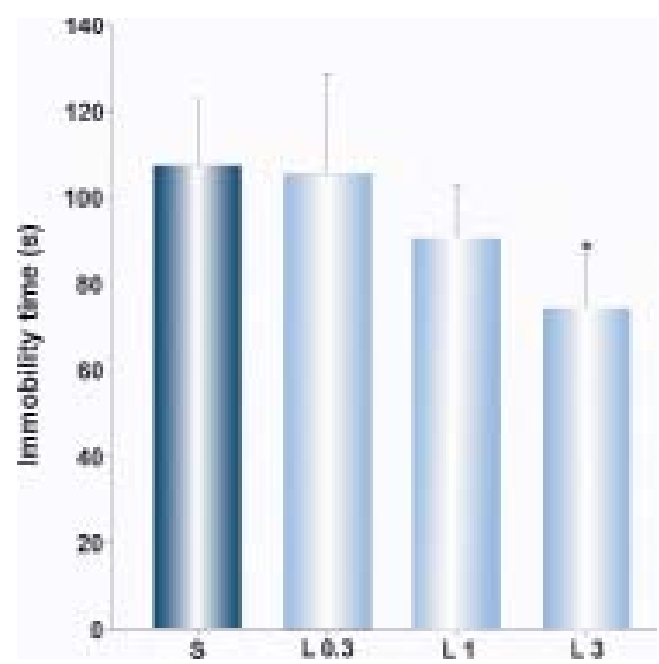

Figure 1. Effects of L-655,708 (L: 0.3, 1, and 3 $\mathrm{mg} / \mathrm{kg}$ ), on the immobility time of the animals in the forced swim test. $* \mathrm{p}<0.05$ compared to solvent group (S).

Number of animals per treatment was 6 .

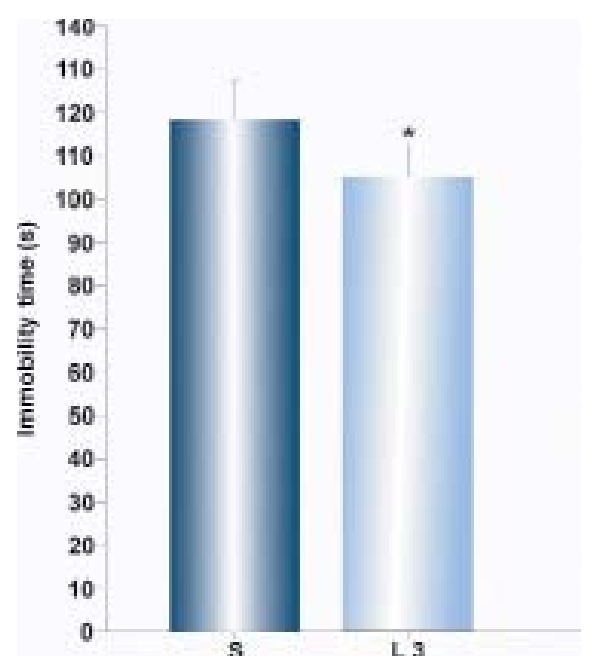

Figure 2. Effects of repeated application of L-655,708 (L: $3 \mathrm{mg} / \mathrm{kg}$ ), on the immobility time of rats in the forced swim test. $* \mathrm{p}<0.05$ compared to solvent group (S). Number of animals per treatment was 6 .

\section{Spontaneous locomotor activity}

Treatment with L-655,708 did not affect the total distance traveled by the animals during $30 \mathrm{~min}$ of monitoring spontaneous locomotor activity $(\mathrm{F}(3,20)=2.59, \mathrm{p}>0.05)$ (Figure 3).

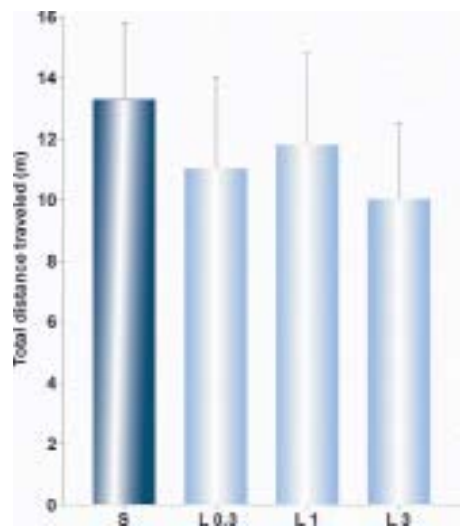

Figure 3. Effects of control (S) and L-655,708 (L: 0.3, 1, and $3 \mathrm{mg} / \mathrm{kg}$ ) on the total distance traveled in the locomotor activity assay. Number of animals per treatment was 6 . 


\section{DISCUSSION}

It was recently recognized that drugs with antidepressant / mood-stabilizing effects significantly alter GABAergic transmission $[17,18]$. Namely, modulation in GABAergic inhibition has been proposed to play an important role in the pathophysiology of depression [19-21]. Data from experimental models demonstrate that the forced swim test represents a reliable and valuable behavioral research model of depression in rodents and also an important tool to study neurobiological mechanisms involved in antidepressant activity. The substances with antidepressant potential significantly reduce the animals' immobility time, which is considered as a reaction of despair and depressiveness [22]. In our study, decreased immobility was clearly observed with L-655,708 (3 mg/ $\mathrm{kg}$ ), after single and repeated administration, which shows its antidepressant-like properties. Furthermore, there was no effect on struggling time, confirming that these effects were not confounded by change in motor function.

L-655,708 possesses in vitro binding selectivity, as well as moderate inverse agonist functional selectivity for the $\alpha 5$-containing GABA-A receptors [11]. Receptors containing the $\alpha 5$ subunit constitute a modest fraction of BZ-sensitive GABA-A receptors (approximately 5\%), but are substantially expressed in several brain regions, most notably the hippocampus, the olfactory bulb and layers V and VI of the neocortex $[9,10]$. Studies with untreated mice with the point mutation at the $\alpha 5$ subunit have indicated the significance of the $\alpha 5$ subunit for learning certain aversively-motivated memory tasks which require temporal integration [23,24]. Our data suggest that negative modulation at GABA-A receptors containing the $\alpha 5$ subunit might have produced the antidepressant effects in rats and that these effects were not confounded by locomotor influences.

Recent animal studies with the inverse agonist selective for $\alpha 5$ GABA-A receptors found improved learning and memory function in models of cognitive defect, suggesting distinctive roles of different subunits [25]. The antidepressant and memory-enhancing effects are in agreement with observations that low mood is frequently combined with anxiety and cognitive impairment [26]. A recently found correlation between helpless behavior and cognition [26,27] was fully supported by our results demonstrating that the antidepresant-like effect was obtained by the same selective agent $(\mathrm{L}-655,708)$ that previously induced memory-enhancing effects. The overall effect of L-655,708 may thus reflect a better performance based on both cognition and motivational enhancements. The results of our study are consistent with previously published data, which demonstrate a role for GABA-A receptors in depressive-like behavior [20, 21, 28, 29]. However, while $\alpha 2$-containing GABA-A receptors are known to be involved in regulating anxietylike behavior [30], our results suggest that $\alpha 5$-containing GABA-A receptors may be involved in depressive-like behavior. To the best of our knowledge, our study is one of the first reports on the influence of a benzodiazepine inverse agonist selective for $\alpha 5$-subunit-containing GABA-A receptors on rat behavior in forced swim test. The observed action was antidepressant and, at first glance, this seems to contradict the view that decreased GABA-A receptor activity enhances depression [17]. But, it should be taken into account, however, that such effects may occur at higher doses of the 
drug. The acute antidepressant effect of GABA-A activation observed here, shows striking similarity to the effects of glutamatergic NMDAR antagonists reported by other authors [31-33]. In these papers, the NMDAR antagonists, after only $30 \mathrm{~min}$, significantly reduced immobility in FST compared to vehicle-treated animals, suggesting that NMDAR blockade produces fast-acting antidepressant responses. Here we report a complementary acute antidepressant action by interfering with the counterbalancing, GABA-ergic system. Similar actions were also found in humans [34].

In conclusion, our results experimentally support the finding that inverse agonists selective for $\alpha 5$ GABA-A receptors produce antidepressant effects, and these effects are not confounded by locomotor influences. The molecular substrates linking the actions of specific GABA-benzodiazepine receptor subunits awaits to be further elucidated and linked to human neuropsychiatric disorders.

\section{ACKNOWLEDGEMENTS}

This work was partly supported by the Ministry of Education, Science and Technological Development of the Republic of Serbia - Grant No. 175076.

The authors have no conflict of interest to declare.

\section{REFERENCES}

1. Olsen RW, Sieghart W: International Union of Pharmacology. LXX. Subtypes of gammaaminobutyric acid (A) receptors: classification on the basis of subunit composition, pharmacology, and function. Update. Pharmacol Rev 2008, 60:243-260.

2. Korpi ER, Grunder G, Luddens H: Drug interactions at GABA(A) receptors. Prog Neurobiol 2002, 67:113-159.

3. Chebib M, Johnston GA: GABA-Activated ligand gated ion channels: medicinal chemistry and molecular biology. J Med Chem 2000, 43:1427-1447.

4. Chapouthier G, Venault P: GABA-A receptor complex and memory processes. Curr Top Med Chem 2002, 2:841-851.

5. Krazem A, Borde N, Béracochéa D: Effects of diazepam and beta-CCM on working memory in mice: relationships with emotional reactivity. Pharmacol Biochem Behav 2001, 68:235-244.

6. Rudolph U, Möhler H: Analysis of GABAA receptor function and dissection of the pharmacology of benzodiazepines and general anesthetics through mouse genetics. Annu Rev Pharmacol Toxicol 2004, 44:475-98.

7. Sieghart W, Ernst M: Heterogeneity of GABAA receptors: reviwed interest in the development of subtype-selective drugs. Curr Med Chem Cent Nerv Syst Agents 2005, 5:217-242.

8. Izquierdo I, Medina JH: Memory formation: the sequence of biochemical events in the hippocampus and its connection to activity in other brain structures. Neurobiol Learn Mem 1997, 68:285-316.

9. Pirker P, Pirker S, Schwarzer C, Wieselthaler A, Sieghart W, Sperk G: GABA(A) receptors: immunocytochemical distribution of 13 subunits in the adult rat brain, Neuroscience 2000, 
101:815-850.

10. Sieghart W, Sperk G: Subunit composition, distribution and function of GABAA receptor subtypes. Curr Top Med Chem 2002, 2:795-816.

11. Atack JR, Pike A, Clarke A, Cook SM, Sohal B, McKernan RM, Dawson GR: Rat pharmacokinetics and pharmacodynamics of a sustained release formulation of the GABAA alpha5-selective compound L-655,708. Drug Metab Dispos 2006, 34:887-893.

12. Chambers MS, Atack JR, Broughton HB, Collinson N, Cook S, Dawson GR, Hobbs SC, Marshall G, Maubach KA, Pillai GV, Reeve AJ, MacLeod AM: Identification of a novel, selective $\mathrm{GABA}(\mathrm{A})$ alpha5 receptor inverse agonist which enhances cognition. J Med Chem 2003, 46:2227-2240.

13. Collinson N, Atack JR, Laughton P, Dawson GR, Stephens DN: An inverse agonist selective for alpha5 subunit-containing GABAA receptors improves encoding and recall but not consolidation in the Morris water maze. Psychopharmacology 2006, 188:619-628.

14. Dawson GR, Maubach KA, Collinson N, Cobain M, Everitt BJ, MacLeod AM, Choudhury HI, McDonald LM, Pillai G, Rycroft W, Smith AJ, Sternfeld F, Tattersall FD, Wafford KA, Reynolds DS, Seabrook GR, Atack JR: An inverse agonist selective for alpha5 subunitcontaining GABAA receptors enhances cognition. J Pharmacol Exp Ther 2006, 316:13351345.

15. Redrobe JP, Elster L, Frederiksen K, Bundgaard C, de Jong IE, Smith GP, Bruun AT, Larsen PH, Didriksen M: Negative modulation of GABAA $\alpha 5$ receptors by RO4938581 attenuates discrete sub-chronic and early postnatal phencyclidine (PCP)-induced cognitive deficits in rats. Psychopharmacology 2012, 221:451-468.

16. Porsolt RD, Anton G, Blavet N, Jalfre M: Behavioural despair in rats: a new model sensitive to antidepressant treatments. Eur J Pharmacol 1978, 47:379-391.

17. Hines RM, Davies PA, Moss SJ, Maguire J: Functional regulation of GABA(A) receptors in nervous system pathologies. Curr Opin Neurobiol 2012, 22:552-558.

18. Kalueff AV, Nutt DJ: Role of GABA in anxiety and depression. Depress Anxiety 2007, 24:495-517.

19. Luscher B, Fuchs T, Kilpatrick CL: GABAA receptor trafficking-mediated plasticity of inhibitory synapses. Neuron 2011, 70:385-409.

20. Earnheart JC, Schweizer C, Crestani F, Iwasato T, Itohara S, Mohler H, Lüscher B: GABAergic control of adult hippocampal neurogenesis in relation to behavior indicative of trait anxiety and depression states. J Neurosci 2007, 27:3845-3854.

21. Shen Q, Lal R, Luellen BA, Earnheart JC, Andrews AM, Luscher B: Gamma-Aminobutyric acid-type A receptor deficits cause hypothalamic-pituitary-adrenal axis hyperactivity and antidepressant drug sensitivity reminiscent of melancholic forms of depression. Biol Psychiatry 2010, 68:512-520.

22. Xing B, Zhao Y, Zhang H, Dang Y, Chen T, Huang J, Luo Q: Microinjection of valproic acid into the ventrolateral orbital cortex exerts an antidepressant-like effect in the rat forced swim test. Brain Res Bull 2011, 85:153-157.

23. Crestani F, Keist R, Fritschy JM, Benke D, Vogt K, Prut L, Blüthmann H, Möhler H, Rudolph U: Trace fear conditioning involves hippocampal alpha5 GABA(A) receptors. Proc Natl Acad Sci USA 2002, 99:8980-8985.

24. Yee BK, Hauser J, Dolgov VV, Keist R, Möhler H, Rudolph U, Feldon J: GABA receptors 
containing the alpha5 subunit mediate the trace effect in aversive and appetitive conditioning and extinction of conditioned fear. Eur J Neurosci 2004, 20:1928-1936.

25. Braudeau J, Delatour B, Duchon A, Pereira PL, Dauphinot L, de Chaumont F, OlivoMarin JC, Dodd RH, Hérault Y, Potier MC: Specific targeting of the GABA-A receptor $\alpha 5$ subtype by a selective inverse agonist restores cognitive deficits in Down syndrome mice. J Psychopharmacol 2011, 25:1030-1042.

26. Elizalde N, Gil-Bea FJ, Ramírez MJ, Aisa B, Lasheras B, Del Rio J, Tordera RM: Longlasting behavioral effects and recognition memory deficit induced by chronic mild stress in mice: Effect of antidepressant treatment. Psychopharmacology (Berl) 2008, 199:1-14.

27. Bondi CO, Jett JD, Morilak DA: Beneficial effects of desipramine on cognitive function of chronically stressed rats are mediated by alpha1-adrenergic receptors in medial prefrontal cortex. Prog Neuropsychopharmacol Biol Psychiatry 2010, 34:913-923.

28. Samardžić J, Štrac DŠ, Obradović M, Oprić D, Obradović DI: DMCM, a benzodiazepine site inverse agonist, improves active avoidance and motivation in the rat, Behav Brain Res 2012, 235:195-199.

29. Vollenweider I, Smith KS, Keist R, Rudolph U: Antidepressant-like properties of $\alpha 2$ containing GABA receptors. Behav Brain Res 2011, 217:77-80.

30. Löw K, Crestani F, Keist R, Benke D, Brünig I, Benson JA, Fritschy JM, Rülicke T, Bluethmann H, Möhler H, Rudolph U: Molecular and neuronal substrate for the selective attenuation of anxiety. Science 2000, 290:131-134.

31. Autry AE, Adachi M, Nosyreva E, Na ES, Los MF, Cheng PF, Kavalali ET, Monteggia LM: NMDA receptor blockade at rest triggers rapid behavioural antidepressant responses. Nature 2011, 475:91-95.

32. Berman RM, Cappiello A, Anand A, Oren DA, Heninger GR, Charney DS, Krystal JH: Antidepressant effects of ketamine in depressed patients. Biol Psychiatry 2000, 47:351-354.

33. Li N, Lee B, Liu RJ, Banasr M, Dwyer JM, Iwata M, Li XY, Aghajanian G, Duman RS: mTOR-dependent synapse formation underlies the rapid antidepressant effects of NMDA antagonists. Science 2010, 329:959-964.

34. Krystal JH, Sanacora G, Blumberg H, Anand A, Charney DS, Marek G, Epperson CN, Goddard A, Mason GF: Glutamate and GABA systems as targets for novel antidepressant and mood-stabilizing treatments. Mol Psychiatry 2002, 7:S71-S80.

\section{ANTIDEPRESIVNI EFEKTI INVERZNOG AGONISTE SELEKTIVNOG ZA $\alpha 5$ GABA-A RECEPTORE U TESTU FORSIRANOG PLIVANJA PACOVA}

SAMARDŽIĆ Janko, PUŠKAŠ Laslo, OBRADOVIĆ Miljana, LAZIĆ-PUŠKAŠ Dijana, OBRADOVIĆ I Dragan

U elektrofiziološkim ispitivanjima pokazano je da ligand L-655,708 poseduje selektivnost u vezivanju i umerenu inverznu agonističku aktivnost za GABA-A receptore koji sadrže $\alpha 5$ podjedinicu. Ova studija ima za cilj ispitivanje antidepresivnih efekata liganda 
L-655,708 u testu forsiranog plivanja (FST) i njegov uticaj na lokomotornu aktivnost kod pacova. Ponašanje životinja je praćeno pomoću digitalne kamere, a podaci su analizirani primenom jednostepene analize varijanse (ANOVA) i Dunett-ovim testom. U testu forsiranog plivanja L-655,708 statistički značajno smanjuje vreme imobilnosti pri dozi od $3 \mathrm{mg} / \mathrm{kg}$, nakon jednokratne i ponavljane primene $(\mathrm{p}<0,05)$, ispoljavajući akutne i hronične antidepresivne efekte. Međutim, nije uticao značajno na vreme provedeno u borbi za preživljavanje tokom FST. Osim toga, L-655,708 nije pokazao značajan uticaj na lokomotornu aktivnost $(\mathrm{p}>0,05)$. Ovi podaci ukazuju da negativna modulacija GABA-A receptora koji sadrže $\alpha 5$ podjedinicu može ispoljiti antidepresivne efekte kod pacova. Ovi efekti su bez izraženih lokomotornih uticaja. 